\title{
Pantun and Syair in the Text of Lullaby Song of Minangkabau Collective in West Sumatra
}

\author{
Hasanuddin $\mathrm{WS}^{1, *}$, Emidar $^{1}$, Zulfadhli $^{1}$ \\ ${ }^{1}$ Indonesian Department, Universitas Negeri Padang, Padang, Sumatra Barat 25131, Indonesia \\ *Corresponding author. Email: hasanuddinws@gmail.com
}

\begin{abstract}
The article on the results of this research contains a discussion of the format of the text of the oral tradition of the Minangkabau collective lullaby song in West Sumatra. The collective area of Minangkabau in West Sumatra consists of mainland areas (Luak) and coastal areas (Rantau). This research is a descriptive qualitative research. Format data were obtained through tracing the physical and inner structure of the lullaby song text from these two collective Minangkabau regions. The study of the format, especially the form of pantun and syair, uses the theory of the structure of poetry as used by Riffaterre (1978), Pradopo (1993), Djamaris, et al. (1993), Teeuw (2000), Rusyana (2000), and Hasanuddin WS, et al. (2020). Based on the research findings, the format and content of the oral tradition text of lullaby song in the mainland area and the coastal area of the Minangkabau collective in West Sumatra have two patterns of poetry format, namely free patterned poetry (sonnet: not tied to lines, stanzas, rhymes) and bound patterns (pantun and syair: tied to an lines, stanza, rhyme, rhythm) that are used simultaneously. The combination of these two poetry forms aesthetically serves to present the beauty of language, a sense of comfort, calm, and wellbeing, as well as to evoke sleepiness for those who listen to it, especially children.
\end{abstract}

Keywords: Pantun, syair, text, oral tradition, folk songs, lullaby songs, Minangkabau collective

\section{INTRODUCTION}

The oral tradition of folk songs to lull children to sleep has attracted many researchers to study it. Many researchers have conducted studies on this oral tradition. The researchers studied both the lyrics or the text of this song, and the song (tone and rhythm) of the sing a song. In fact, this oral tradition is owned by almost all collective societies and nations. Therefore, it is not surprising that every ethnicity and nation has conducted a study of its oral tradition. Of course the studies that have been carried out by these researchers have a variety of purposes and interests. Minangkabau researchers likewise. They have also conducted various studies on this oral tradition.

As far as the author's observations, Minangkabau researchers have only conducted a partial study of the oral tradition of the lullaby song belonging to its collective. On the other hand, studies of the oral tradition of the of lullaby song of Minangkabau collective by researchers from outside the Minangkabau have yet to be found. The study conducted by researchers from Minangkabau focused more on one scientific study, for example linguistics in semantic studies or a focus on one type of Minangkabau lullaby song found in a kanagarian (village) in an area in West
Sumatra. Partial research includes, for example, conducted by Salahuddin [1], Marantes, et al. [2], Fitriana [3], Salahuddin conducted research on Maondu Pojo's lullaby song in Kapur IX Kabupaten Lima Puluh Kota (Lima Puluh Kota Regency) and Fitriana conducted research on the lullaby song of Nandong in Kabupaten Kuantan Sengingi (Kuantan Sengingi Regency). Marantes, et al., Conducted a linguistic study, namely a semantic study of several texts of the oral tradition of the Minangkabau collective lullaby song from several random locations. Hasanuddin WS, et al. [4] and [5] conducted research with a wider scope of areas, namely the mainland area (Luak) and the coastal area (Rantau) of the Minangkabau collective in West Sumatra. However, the study conducted by Hasanuddin WS, et al. [19]. On the text of oral tradition of the Minangkabau collective lullaby song, only focused on the study of the format, content and function of the text.

The discussion in this article is a further study of the results of a study on the format of the oral tradition of the Minangkabau collective lullaby song in West Sumatra which has been carried out by Hasanuddin WS, et al. [4] and [5]. One of their previous findings was the format of the oral tradition texts of the lullaby song in the mainland area (Luak) and also the coastal area (Rantau) of the Minangkabau collective in West 
Sumatra in the form of a combination of free patterned poetry (sonnet: not tied to lines, stanzas, rhymes, and rhythms). ) and bound pattern poetry (pantun and syair: tied to lines, stanzas, rhymes, rhythms). The fact of this finding shows that the text of the oral tradition of the Minangkabau collective lullaby song in West Sumatra is a phenomenon of harmonization between elements of tradition and modernity. The Minangkabau collective in West Sumatra maintains and or adapts traditional elements to the elements of modernity as an effort to maintain the preservation of traditions in the lives of the people who continue to modernize. The ability to incorporate elements of tradition in modernity by the Minangkabau collective is actually something to be admired. This phenomenon is interesting to study further. This is because the follow-up study is also a stage to explain a number of things about collective social behavior in Minangkabau. The formulation of this understanding is important because the relationship between tradition and modernization that takes place in harmony can be considered as basic values that have "unified" the Minangkabau collective into a collective that can contribute to life together with other collectives in the life of the nation in this archipelago. Another important thing, this study of the collective tradition of Minangkabau is also an effort to record and document an oral tradition of lullaby song belonging to the Minangkabau collective which is slowly being abandoned and may disappear due to the challenges of its collective situation and condition.

The theory of traditional poetry and modern poetry is the basis for an examination of the format, content, and function of pantun and syair patterns in the oral tradition of the Minangkabau collective lullaby song in West Sumatra. This has been done by many researchers, including Riffaterre [6], Junus [7], Pradopo [8], Djamaris, et al. [9], Teeuw [10], Rusyana [11], and Hasanuddin WS. et al. [4] and [5]. Thus, the study of the format, content, and function of pantun and syair in the oral tradition of the Minangkabau collective lullaby song in West Sumatra is a structural study.

The text of the Minangkabau collective lullaby song in West Sumatra can be summed up as a poetry text. As poetry, the text of the lullaby song can be studied based on two formats. The first format is the physical format (in the form of typography: lines and couplets; diction; images; concrete words; figurative language; and versification). The second format is the inner format (in the form of theme, message, tone and atmosphere). In addition, the oral tradition of the lullaby song is a functional type of folk song. That is, the oral tradition that functions is if between the songs, the tone, rhythm, and the text have the same strength. Their roles are equally important. So, this oral tradition is said to function because the song, tone, rhythm, and text are in lines with special situations and conditions in people's daily activities.

The physical format of the lullaby song studied in this discussion is a combination of formats between free poetry formats (sonnets: not tied to lines, stanzas, rhymes and rhythms) and bound poetry formats (pantun and syair as a traditional of Minangkabau poetry: tied to lines, stanzas, rhymes and rhythms). The songs, tones, and rhythms of these Minangkabau collective lullaby songs in West Sumatra are lyrical, subtle, and calm songs, tones, and rhythms. The text or lyrics are always sung over and over. The words contained in the lyrics are words of affection and seduction. Such situations and conditions can bring a sense of comfort, peace, and invite drowsiness to listeners, especially children who are being persuaded to fall asleep.

\section{METHOD}

This article is compiled based on the results of qualitative research. What is meant by qualitative research here is that research is carried out without being processed statistically, not using numbers, but giving priority to the researchers' appreciation of the interactions between the concepts being studied empirically. This is done in order to understand the phenomena experienced by the research subjects. The phenomena referred to are, among others, perceptions, motivations, behaviors, actions, holistically, with a specific natural context, and by utilizing the scientific method.

This research is a research that produces descriptive data in the form of written or spoken words from people and observable behavior, depending on observations in humans, both in their area and in their terms. This research prioritizes natural settings and is carried out to present the social world and its perspectives in the world in terms of concepts, behavior, perceptions, and problems about the human being studied.

The text of the oral tradition of the lullaby song was obtained from informants from the Minangkabau people who sing the lullaby people who live in the mainland (Luak) and coastal areas (Rantau). The three Luak regions (Tanah Datar, Agam, Limo Puluah Koto) were expanded to one other area beyond the three Luak that have been mentioned earlier, namely the Solok region representing the mainland area. The coastal area (Rantau) is represented by three regions (Padang, Padangpariaman, and Pesisir Selatan).

The data of this study are data on the format, content, and function of pantun and syair in the oral tradition of the Minangkabau collective lullaby song in West Sumatra. The data were collected in two stages. First, after going through a literature study, recording of the utterances uttered (hummed) by the informants was carried out. The recordings were transcribed into written form. The results of the transcription were then transliterated from the Minangkabau language into Indonesian. The transliterated text is then examined for the format of the text, especially those related to pantun and syair texts. Furthermore, an assessment of the elements of content and function is carried out using the theory as previously described. Second, through the 
technique of recording, observing, and interviewing data about the storytelling environment, including the views and philosophy of life, as well as the life values of the speaking community who owns the oral tradition of the Minangkabau collective lullaby song in West Sumatra.

\section{RESULTS AND DISCUSSION}

\section{Text Format: Pantun and Syair}

The text of the Minangkabau collective lullaby song in West Sumatra, based on its format, is more suitable to be categorized as a poetry format. In general, the format of the Minangkabau collective lullaby song text in West Sumatra can be said to be a free poetry format, namely poetry whose lines, stanzas, rhymes, and rhythms are not tied to a particular pattern. The singer of the song has an important role in how the lines and stanzas of poetry are produced. What importance is conveyed in chanting the text will produce certain lines and stanzas. If the chanter wants to convey a message or advice, the resulting lines and stanza will be different than when the singer is singing seduction or persuasion. In principle there are no clear rules about lines and stanzas. The chanter can do the repetition of lines and even stanzas many times for the purpose of emphasizing the purpose he wants to convey.

In the fact that the singer is so free to produce lines and stanzas of this lullaby song, we find poetry texts that are patterned and organized. The lullaby songs produced by several singers are found in their texts that there are regular lines and stanzas that are tied to a certain pattern, which is tied to the rules of lines, stanza, rhyme, and rhythm. Texts that are patterned, regular, and bound to the provisions of lines, stanzas, rhymes, and rhythms are known as the Minangkabau collective old poetry (tradition) form. Poetry that is patterned with certain rules is referred to as pantun (tied to a tighter pattern) and syair (having a slightly looser pattern than pantun). The findings of the pantun format and the syair format in the text of the Minangkabau collective lullaby song in West Sumatra shows that the Minangkabau collective effort to maintain its traditional culture or even difficult to let go of the collective tradition even though it has lived in a more open and modern era.

The poetry form of the pantun in each line consists of nine to twelve syllables. Nothing less and nothing more. In one verse, the type of pantun poetry found in the text of the Minangkabau collective lullaby song in West Sumatra is only a pantun consisting of four lines. In a pantun, the final sound (rhyme) in the first lines must be the same as the ending sound in the third lines and the end sound of the second lines must also be the same as the ending sound in the fourth lines. The first two lines are referred to as sampiran (introduction). The last two lines are referred to as content (intent or purpose). This final sound element in pantun is called the final sound pattern (a-b-a-b).

Note the rhyme (final sound) of the poetry in the pantun format found in the lullaby song text of the Dendang
Lolok from Jorong Babusalam Nagari Koto Tuo Kecamatan Sungai Tarab Kabupaten Tanah Datar (from the Minangkabau mainland region) below.

Anak kanduang sibiran tulang ubek jariah nak palarai damam Anak kanduang copeklah godang ka pambangkik nak batang tarandam

\section{Anak kanduang copeklah lolok piciangkan mato dangalah dendang Jikok awak nak parangainyo elok tantu banyak nak urang nan sanang}

Tangih jo apo ka dibujuak tangih baurai jo aia mato Nan kok gadang anak mande isuak usahlah nasib bak mande pulo

Urang mamanciang di hari komi abi kulik nak dek paneh hari Mande manyanyi mancari piti untuak nak kanduang sasuok nasi

Pariangan nak tadanga runtuah urang babaliak nak inggo jalan Dima hati indak ka rusuah malang bana nak untuangnyo badan

The same thing that has been stated above, is also found in the text of the lullaby song of the Manjujai Anak from Kampuang Tabek Jorong Koto Tingga Nagari Sirukam Kecamatan Payung Sekaki Kabupaten Solok (also from the Minangkabau mainland region) below.

Ampang Kualo pacuan kudo
rami dek anak lai Tanah garam
Oi nak kanduang sayangnyo bundo
paubek jariah palarai damam

Layang-layang tabang malayang inggok di pagaran baniah Baitu elok urang sumbayang ati e elok muko e janiah
Simpang Tabek nagari Sirukan di sinan bundo manggaleh singgang Nak sayang bundo balahan badan capeklah gadang rajin sumbayang

In the text of the lullaby song in the Minangkabau collective coastal area, there is also a pantun format as found in the text of the Malalokan Anak lullaby song from Kampuang Balik Jalan Sungai Pisang Kelurahan Teluk Kabung Tengah Kecamatan Bungus Teluk Kabung Padang City below.
Panjeklah silawik tenggih-tenggih tibo di bawah lah pacah oi balah Tingkek lah ilmu nak oi tenggih-tenggih Iduik paguno biko diridhai Allah 
Tanjuang katuang nak aianyo biru Di siko tampek nak oi mancuci muko sadang sakampuang nak oi ati taibu apolah lai nak oi jauh di mato

Matoari nak oi di baliak awan Ari kalam nak oi rasonyo malam Ndak elok oi nak bujang jikok malawan Kok palawan nak oi awak ka badoso

In the text of the lullaby song in other Minangkabau collective coastal areas, there are also poetry in the format of the pantun as found in the lullaby song text of the Malagu Anak ka Lalok from Korong Tanjung Pisang Nagari Sintuak Kecamatan Sintuak Toboh Gadang Kabupaten Padang Pariaman below.

Jikok kito nak oi pai sikola jan lupo nak oi mambao buku Jikok nak oi wak e kughang aja Buliah nak oi kanai paninju

Sabalun wak e pai ka koto jan lupo nak oi mambali sagun Sabalun kito nak oi manjadi tuo jan pulo sampai nak oi manjadi pikun

Jikok kito wak e pai ka balai jan lupo nak oi mambali sapu Jikok kito wak e nak jadi pandai acok-acok nak oi mambaco buku

Eloklah tidua dalam buaian supayo jan jatuah baguliang-guliang Jikok kito nak oi iduik panyagan jan pulo sampai nak oi jadi pamaliang

The final sound equation at the end of the first and third lines and in the second and fourth lines in each of the above stanzas appears as an important part of the pantun format found in the Minangkabau collective lullaby song text above. Lullaby song text of the Dendang Lolok from Jorong Babusalam Nagari Koto Tuo kecamatan Sungai Tarab Kabupaten Tanah Datar (mainland area), lullaby song text of the Manjujai Anak from Kampuang Tabek Jorong Koto Tingga Nagari Sirukam Kecamatan Payung Sekaki Kabupaten solok (mainland area), text of the lullaby song of the Malalokan Anak from Kampung Balik Jalan Sungai Pisang Kelurahan Teluk Kabung Tengah Kecamatan Bungus Teluk Kabung Kota Padang (coastal area), and the lullaby song text of the Malagu Anak ka Lalok from Korong Tanjung Pisang Nagari Sintuk Kecamatan Sintuk Toboh Gadang Kabupaten Padang Pariaman (coastal area) which is sung in the poetry format of the pantun seems to have been created by the chants in such a way as to create an aesthetic impression.
In other data, namely the data of the lullaby song of the Lalok Nak Oi from Longuang Mandahiliang Nagari Pagaruyuang Kecamatan Tanjung Emas Kabupaten Tanah Datar (mainland area) places the final sound (rhyme) with a sound that tends to be the same at the end of each line in each stanza.

\section{Laloklah nak oi laloklah sayang Nak kanduang kini oi sibiran tulang Nak kanduang dijago oi malam jo siang Ubeknyo jariah nak oi palapeh malang \\ Usahlah nak oi manangih juo \\ Urang panangih nak oi lambek gadangnyo Jikok parusuah capek nak oi kito tuonyo Usahlah nak oi manangih juo}

Kok rancak nak oi anak amak juo Kok buruak nak oi anak amak juo Kok lah godang antah sia nan punyo Kok lah godang antah sia nan punyo

The poetry form with the pattern as above is a bound poetry pattern in the form of poetry in syair format. In terms of the number of syllables, in each line and the number of lines in one verse of poetry, the syair format is not too different from the pattern of the number of syllables in each line and the number of lines in each verse of the poetry in the pantun format. The difference is that in poetry in the syair format, there is no lines of sampiran (introduction) and content lines (intent or purpose). The four lines in each verse in the syair format are the contents. In addition, the final sound (rhyme) equation for the four lines in one stanza is the same. Therefore, the final sound (rhyme) pattern found in this syair format is called the final sound (rhyme) pattern (a-a-a-a).

In the text of the lullaby song in the coastal area of the Minangkabau collective, there are also poetry in the syair format as found in the lullaby song text of the Dendang Malalokan Anak in Kampung Kapencong Kanagarian Koto Berapak Kecamatan Bayang Kabupaten Pesisir Selatan below.

Ramo-ramo nak oi sikumbang janti Tabang inggok nao oi baganti-ganti Iduik ko rumik nak oi elok baati-ati Salamaik iduik nak oi salamaik diri

Rami urang nak oi carocok lauik Pai manangkok nak oi ikan jo pukaik Jalan luruih nak oi padoman iduik Sampai badan nak oi dijapuik mauik

Rancak jari nak oi kuku bainai Rancak badan nak oi ameh bapakai Rancak iduik nak oi elok parangai Rancak badan nak oi sampai takulai 
Sound elements with a pattern (a-a-a-a) in the lullaby song text of the Lalok Nak Oi from Longuang Mandahiliang Nagari Pagaruyuang Kecamatan Tanjung Emas Kabupaten Tanah Datar (mainland area) and the lullaby song text of the Dendang Malalokan Anak from Kampung Kapencong Kanagarian Koto Berapak Kecamatan Bayang Kabupaten Pesisir Selatan (coastal area) above, resulting in a text with a poetry ending sound (rhyme) pattern in syair format. There is the same regularity at the end of the line within each stanza, that is, the same ending sound or rhyme. Poetry in syair format, like poetry in pantun format, has a total of four lines in each stanza. If a certain consonant is the final sound (rhyme) in the first line, then the next lines in the stanza will sound the same as the consonant. If a certain vowel sound is the final sound (rhyme) in the first line, then the next lines in the stanza will have the same vowel sound.

Different from the type of free poetry pattern text, the text of the Minangkabau collective lullaby song in West Sumatra is in the form of poetry in the form of pantun and poetry in the syair format which is not repeated in the chanting. What is often repeated (repetition) is the part of the song text in the form of free format text (sonnet). In both the mainland areas (Luak) and coastal areas (Rantau), it seems that the lullaby singer has the same character, that is, they tend to only repeat chants for types of lines and free-form poetry stanzas. The repetition of the same words and sounds in free-form poetry texts in addition to presenting a rhythm and meter that creates a comfortable atmosphere, the repetition is also a sign that the word or series of words being repeated is an important word or series of words.

\section{Text Content: Pantun and Syair}

The contents of the poetry text in the form of pantun and poetry in the syair format in the oral tradition of the lullaby song of Minangkabau collective in West Sumatra are generally a portrait of the feelings and thoughts of people who sing the lines and stanzas of the text. The singer of this kind of folk song can actually be anyone, (maybe the mother of the baby, the mother of mother's the baby, the father of the baby, it can also be the father of the baby's father, other close family members, and so on), or someone who might be do not have a direct blood relationship with the baby. The main purpose of the chanting of the song text is so that the baby or child is led to sleep. Therefore, it is not unusual if the contents of the poetry text in the form of pantun and poetry in the syair format contained in the text of the lullaby song are in the form of expressions of feelings of affection, desires, hopes, and prayers for the baby or Children are happy later in their lives so that they can be proud of their father's mother and their extended family. In line with this, Goodenough (1981), Navis (2002), Sedyawati (2007), and Marantes, et al. (2018), explain that the poetry text in the pantun format or poetry in the syair format can be recited repeatedly and spontaneously because the poetry text in the form of pantun and poetry in the syair format is very familiar to the singer, at least the patterns and rules that apply to it. chant and rhyme. The above researchers also state that conditions and situations like this are what cause the inner relationship between adults and children to be good.

The contents of the poetry text in the pantun format and poetry in the syair format in the lullaby song text can serve as a medium in an effort to help shape children's personalities to be calmer. Poetry text in pantun format and poetry in syair format in the lullaby song text consists of words from various expressions of affection and also prayers or hopes that the child will prosper in the future. Therefore, most of the contents of the text of the lullaby song of the Minangkabau collective in West Sumatra can certainly contain advice, messages, hopes, and prayers.

The contents of the poetry text in the form of pantun and poetry in the format of syair in the text of the text of lullaby song of Minangkabau collective in West Sumatra are the main and important thing as a medium for the bonding of inner and social relationships between adults and babies or toddlers. Through the text and through the tone and rhythm of the song's text in the pantun format and poetry in the syair format contained in the lullaby song, one side of the baby's personality character is formed from the very beginning. In addition, the poetry text in the form of pantun and syair format in the text of the lullaby song of Minangkabau collective in West Sumatra can be stated as a tangible product of the Minangkabau collective thinking that was born, grew, and developed in West Sumatra to continue to be able to have human sensitivity and satisfy it and offer a cultural value orientation for who hear and those who enjoy the singing of these lullaby folk songs.

\section{Text Functions: Pantun and Syair}

Poetry text in the form of pantun and poetry text in the format of syair in the oral tradition of the Minangkabau collective lullaby song in West Sumatra has at least three main functions, namely the expressive function, the directive function, and the aesthetic function. The following are several verses of poetry in the form of poetry and poetry in poetry that show the expressive function of the singer.

\section{Tangih jo apo ka dibujuak tangih baurai jo aia mato Nan kok gadang anak mande isuak usahlah nasib bak mande pulo}

\section{Urang mamanciang di hari komi abi kulik nak dek paneh hari Mande manyanyi mancari piti untuak nak kanduang sasuok nasi}

\{Poetry text in the pantun format in the lullaby song text of the Dendang Lolok from Jorong Babusalam Nagari 
Koto Tuo Kecamatan Sungai Tarab Kabupaten Tanah Datar)

\author{
Ampang Kualo pacuan kudo \\ rami dek anak lai Tanah garam \\ Oi nak kanduang sayangnyo bundo \\ paubek jariah palarai damam
}

Layang-layang tabang malayang

inggok di pagaran baniah

Baitu elok urang sumbayang

ati e elok muko e janiah

(Poetry text in pantun format in the text of lullaby song text of the Malagu Anak ka Lalok from Korong Tanjung Pisang Nagari Sintuk Kecamatan Sintuk Toboh Gadang Kabupaten Padang Pariaman)

Laloklah nak oi laloklah sayang Nak kanduang kini oi sibiran tulang

Nak kanduang dijago oi malam jo siang Ubeknyo jariah nak oi palapeh malang Usahlah nak oi manangih juo

Urang panangih nak oi lambek gadangnyo

Jikok parusuah capek nak oi kito tuonyo

Usahlah nak oi manangih juo

Kok rancak nak oi anak amak juo

Kok buruak nak oi anak amak juo

Kok lah godang antah sia nan punyo

Kok lah godang antah sia nan punyo

(Poetry text in the syair format in the lullaby song text of the Lalok Nak Oi from Jorong Longuang Mandahiliang Nagari Pagaruyuang Kecamatan Tanjung Emas Kabupaten Tanah Datar)

The function of the directive as a function of both poetry text in the pantun format and poetry in the syair format in the Minangkabau collective lullaby song text in West Sumatra can be seen in the example below. Poetry text in pantun format and poetry in syair format function as a medium for cultivating character education values and moral values (see also Danandjaja (2003), Djamaris, et al. (1993), Rusyana (2000), and Hasanuddin WS, et al. (2020 and 2021) The form in the poetry text in the pantun format and the syair format is in the form of advice, hope, and prayer.

\section{Layang-layang tabang malayang inggok di pagaran baniah \\ Baitu elok urang sumbayang ati e elok muko e janiah}

Simpang Tabek nagari Sirukan di sinan bundo manggaleh singgang

Nak sayang bundo balahan badan capeklah gadang rajin sumbayang
(Poetry text in pantun format in the lullaby song text of the Manjujai Anak from Kampuang Tabek Jorong Koto Tingga Nagari Sirukam Kecamatan Payung Sekaki Kabupaten Solok)
Ramo-ramo nak oi sikumbang janti Tabang inggok nao oi baganti-ganti Iduik ko rumik nak oi elok baati-ati Salamaik iduik nak oi salamaik diri
Rami urang nak oi carocok lauik Pai manangkok nak oi ikan jo pukaik Jalan luruih nak oi padoman iduik Sampai badan nak oi dijapuik mauik

Rancak jari nak oi kuku bainai
Rancak badan nak oi ameh bapakai
Rancak iduik nak oi elok parangai
Rancak badan nak oi sampai takulai

(Poetry text in the syair format in the lullaby song text of the Dendang Malalokan Anak from Kampung Kapencong Kanagarian Koto Berapak Kecamatan Bayang Kabupaten Pesisir Selatan)

The third function is an aesthetic function. The series of expressions of feelings, advice, messages, hopes or prayers contained in the poetry text in the pantun format and the syair format in the text of the Minangkabau collective lullaby song in West Sumatra are not merely chanted without any particular basis. The chant of the poetry text in the pantun format and the poetry in the syair format is creatively processed by the singer through word choice (diction) so that it becomes a poetry text that has aesthetic value. All texts of the Minangkabau collective lullaby song in West Sumatra in the form of poetry in the form of pantun and syair formats that have been compiled in this study can be concluded that they have an aesthetic function (see also Riffaterre (1978), Junus (1981), Pradopo (1993), and Teeuw (2000).

In particular, the text of the Minangkabau collective lullaby song in West Sumatra which is processed in the poetry text in the pantun format and the syair format produces the final sound (rhyme) with a bound pattern. This format also generates a constant meter for each line because of the constant number of syllables in each line. The same pattern was found of lulaby song singers in mainland areas (Luak) and coastal areas (Rantau) of singers, namely the pattern of combining traditional poetry (pantun format and syair format) with modern poetry (sonnet). These findings can be concluded as follows that elements of tradition and modernity can still run harmoniously in the collective life of Minangkabau in West Sumatra. Thus, the research findings in the form of the format, content, and function of poetry text in the pantun and syair form in the oral tradition text of the Minangkabau collective lullaby song in West Sumatra opens up other possibilities for 
further research on collective oral tradition texts other Minangkabau. Mainly for the types of folk songs, namely the play songs and working songs. According to Siegel (1979), Goodenaugh (1981), Hadi (2002), Navis (2002), Barthes (2003), Dundes (2005), and Sedyawati (2007), the earlier it will be better because it will be able to maintained the authenticity of the text. It can be assumed that there will be a big influence from outside culture if research on this kind of thing is delayed. The delay in research will also cause the latest communication technology inventions to influence the singers in singing their folk songs.

\section{CONCLUSION}

The text of the oral tradition of the Minangkabau collective lullaby song in West Sumatra is presented in a literary format, namely free or modern poetry (sonnet) and old or bound poetry (pantun and syair) which contains values, life philosophy, descriptions of attitudes and behavior, and anything thought by the Minangkabau collective in West Sumatra. Thus, the text of the lullaby song of Minangkabau collective in West Sumatra can be understood as both knowledge and local wisdom of the Minangkabau collective in living life. Poetry texts in the pantun format and poetry texts in the syair format in the Minangkabau collective lullaby song text in Minangkabau constitute a very valuable intangible cultural heritage. The text of the Minangkabau collective Lullaby song in West Sumatra is able to function as a medium for carrying out the expressive function, directive function, and aesthetic function of the Minangkabau collective. Thus, it can be understood that like other oral traditions, the text of the Minangkabau collective lullaby song in West Sumatra not only has a pragmatic aesthetic function of language in speech, but also other broader social functions.

The text of the oral tradition of lullaby song of the Minangkabau collective in West Sumatra as an intangible cultural heritage has other social functions as well, namely as a projection system; as a means of ratification of social institutions; as a means of children's education; and as a means of coercing and monitoring the norms of society so that they are always obeyed. The oral tradition text of the Minangkabau collective lullaby song in West Sumatra is a means of communication in terms of self-control and the inculcation of the main character values in the Minangkabau collective for generations.

\section{ACKNOWLEDGMENTS}

The authors would like to thank Lembaga Penelitian dan Pengabdian Masyarakat Universitas Negeri Padang for funding this work with a contract number: 761/UN35.13/LT/2021

\section{REFERENCES}

[1] Salahuddin, Amar. (2014). Tradisi Lisan Maondu Pojo: Senandung Menidurkan Anak Masyarakat KabupatenLima Puluh Kota Sumatera Barat. Padang: Suka Bina Press.
[2] Marantes, Kasmi Waldisen, Lindawati, Eka Meigalia. (2018). "Pemaknaan terhadap Dendang Mengasuh Anak (Kajian Semantik)". Jurnal Elektronik Wacana Etnik Vol. VII No. 1 April 2018, p. 11-18, ISSN 2089-8746 (p), ISSN 2302-7142 (e).

[3] Fitriana, Riri Amanda. (2019). "Nilai-Nilai Tunjuk Ajar Melayu di Dalam Teks Nandong di Kecamatan Pangean Kabupaten Kuantan Singingi" Tesis Program Magister. Padang: Program Magister Pendidikan Fakultas Bahasa dan Seni Universitas Negeri Padang.

[4] Hasanuddin WS, Emidar, Zulfadhli. 2020. "Text of Oral tradition of Lullaby Songs Mainland Region of the Minangkabau Collective: Format, Content, and Functions" in Proceeding International Conference Language, Literature and education (ICLLE 2020) on August 12-13, Padang, Anvanced in Social Science, Education and Humanities Research, Volume 485, p. 147-159, ISBN 978-94-6239-271-7, ISSN 2352-5398, DOI htpps://10.2991/assehr.k.201109.025, Published by Atlantis Press.

[5] Hasanuddin WS, Emidar, Zulfadhli. 2021. "Social Function of Text of Oral Tradition of Lullaby Song Coastal Region of Minangkabau Collective in West Sumatra" in Proceeding International Conference Language and Art (ICLA 2020) on October 14-15, Padang, Anvanced in Social Science, Education and Humanities Research, Volume 539, p. 100-110, ISBN 978-94-6239-358-5, ISSN 2352-5398, DOI htpps://10.2991/assehr.k.210325.018, Published by Atlantis Press 26 March 2021.

[6] Riffaterre, Michael. (1978). Semiotict of Poetry. Bloomington: Indiana University Press .

[7] Junus. Umar. 1986. Sosiologi Sastra: Persoalan Teori dan Metode. Kuala Lumpur: Dewan Bahasa dan Pustaka.

[8] Pradopo, Rachmat Djoko. 1993. Pengkajian Puisi. Yogyakarta: Gadjah Mada University Press.

[9] Djamaris, Edwar, dkk. (1993). Nilai Budaya dalam Beberapa Karya Sastra Nusantara: Sastra Daerah di Sumatera. Jakarta: Pusat Pembinaan dan Pengembangan Bahasa

[10] Teeuw, A. (2000). Sastra dan Ilmu Sastra: Pengantar Teori Sastra. Jakarta: Pustaka Jaya

[11] Rusyana, Yus. (2000). Prosa Tradisional: Pengertian, Klasifikasi, dan Teks. Jakarta: Pusat Bahasa Departemen Pendidikan Nasional

[12] Siegel, James. (1979). Shadow and Sound: The Historical Thought of a Sumatran People. Chicago: University of Chicago Press 
[13] Danandjaja, James. (2003). Folklore Amerika: Cermin Multikulturalisme yang Manunggal. Jakarta: Grafiti Press

[14] Sedyawati, Edi. (2007). Keindonesiaan dalam Budaya. Jakarta: Wedatama Widya Sastra

[15] Dundes, A. (Ed.) 2005. Folklore: Critical Concept in Literary and Cultural Studies. Vol. I-III . London: Routledge

[16] Goodenough, Ward H. (1981). Culture, Language, and Society. California: Cummings Publishing Company

[17] Hadi, Wisran. (2002). "Menyikapi Terjadinya Krisis Identitas dalam Masyarakat Minangkabau" Makalah Seminar Internasional "Indonesia in Transition". Padang: Fakultas Sastra Universitas Andalas Padang

[18] Barthes, Roland. (2003). Mitologi (translate by Christian Ly). Bandung: Dian Aksara Press

[19] Hasanuddin WS. (2016). “ The Intangible Cultural Heritage of Minangkabau traditional Expression: The Local Wisdom of the Cociety in Advising and Noble Advicing" in Jurnal Jumanus: Jurnal Ilmiah Ilmu-ilmu Humaniora Vol. XV (2) p. 131-141, PRINTED ISSN 1410-8062, ONLINE ISSN 2928-3936, Sinta-2 National Accreditation

[20] Koentjaraningrat. (2009). Ilmu Antropologi (Edisi Revisi). Jakarta: Rineka Cipta

[21] Koentjaraningrat. (1977). Metode-metode Penelitian Masyarakat. Jakarta: Gramedia

[22] Navis, A.A. (2002). "Perkisaran Orientasi Masyarakat Minangkabau dari Masa ke Masa" Makalah Seminar Internasional "Indonesia in Transition". Padang: Fakultas Sastra Universitas Andalas

[23] Sims, M.C. and Martine, S. (2011). Living Folklore: An Introduction to the Study of People and Their Traditions. Logan Utah: Utah State University Press 